\title{
PENGEMBANGAN MODEL PENDIDIKAN MULTIKULTUR BERBANTUAN MODUL BERBASIS MASALAH YANG BERORIENTASI PADA SPIRITUALISME DALAM PEMBELAJARAN IPS - SD
}

\author{
Sudiatmaka, $\mathrm{K}^{1}$. dan W. Lasmawan ${ }^{2}$ \\ 1, 2 Jurusan PPKn, Fakultas IImu Sosial, Universitas Pendidikan Ganesha \\ Singaraja, Indonesia
}

e-mail: lasmawanizer@yahoo.com

\begin{abstract}
Abstrak
Penelitian ini bertujuan untuk mewujudkan model pendidikan multikultur sekolah dasar dan perangkat pembelajarannya yang terdiri dari: (1) model pendidikan multikultur SD, (2) perangkat evaluasi yang sesuai dengan karakteristik Kurikulum 2006. Untuk mendapatkan jawaban yang empiris, data dalam penelitian ini dikumpulkan dengan studi pustaka, lembar validasi, lembar observasi, angket, tes hasil belajar dan wawancara. Hasil penelitian menunjukkan bahwa: (1) candraan materi dan kompetensi mata pelajaran IPS di kelas-kelas awal sekolah dasar secara umum berisikan kompetensi yang terkait dengan: lingkungan, kesenangan diri (hobi), kebersihan, kerjasama, dan tempat-tempat umum (public area). (2) Pengembangan dilakukan dengan mekanisme sebagai berikut: fokus group discussion, individual perspektif, seminar dan lokakarya, simulasi model, dan justifikasi dan validasi model. (3) Bentuk akhir dari model pendidikan multikultur dalam pembelajaran IPS menganut paradigma sekuensi-karakteristik materi. (4) Bentuk dari instrumen penilaian pendidikan multikultur yang visibel untuk dikembangkan antara lain: self-esteem, penilaian kinerja, skala sikap, tes keterampilan sosial, penilaian literasi sosialbudaya, skala sikap, tes keterampilan berpikir, dan yang lainnya. (5) Bentuk akhir dari model pembelajaran berbasis multikultur terdiri dari komponen-komponen yang sinergis mutualis, dan (6) Siswa yang dibelajarkan dengan model pembelajaran berpendekatan multikultur memiliki prestasi belajar yang lebih baik dibandingkan dengan siswa yang dibelajarkan dengan model konvensional, baik pada siswa yang memiliki sikap spiritualisme tinggi, maupun siswa yang memiliki sikap spiritualisme rendah.
\end{abstract}

Kata kunci: modul berbasis masalah, pendidikan IPS, pendidikan multikultur 


\begin{abstract}
This research aimed at realizing a multicultural education model in elementary school and learning tools consisting of: (1) model of multicultural primary education, (2) evaluation tools which are associated with the characteristics of Curriculum 2006. For obtaining empirical answers, the research data were collected by conducting library research, validation sheet, observation sheet, questionnaire, result try out and interview. The results of this study showed that: (1) The arranged materials and competencies of social science in the early grades of primary school generally contains of the competencies which are related to: environment, pleasure (hobbies), hygiene, cooperation, and public places (public areas). (2) The development was performed with the following mechanism: focus group discussions, individual perspective, seminars and workshops, simulation models, and the justification and validation of the model. (3) The final form of the multicultural learning model in social science instruction involved sequence paradigm of material characteristics. (4) The form of multicultural education assessment instrument that is visible to be developed include: self-esteem, performance assessment, the scale of attitudes, social skills test, assessment of socio-cultural literacy, the scale of attitudes, thinking skills test, and others. (5) The final form of multicultural-based learning model consists of components which are mutually synergist.. Moreover (6) Students who are taught by using multicultural learning approaches reached better achievements than students who are taught by using conventional model. It was applied on both students who have the attitude of high spiritualism and low spiritualism.
\end{abstract}

Keywords: problem-based modules, social science instruction, multicultural education.

\section{PENDAHULUAN}

Negara Indonesia adalah sebuah komunitas yang unik dan sangat multi etnis, agama, budaya, dan bahasa (Muqtafa, 2008). Identitas ini merupakan kebanggaan sekaligus ancaman bagi kedirian bangsa Indonesia. Oleh sebab itu, upaya internalisasi paham dan perilaku multikultur merupakan kewajiban setiap insan Indonesia agar keutuhan negara kesatuan republik indonesia (NKRI) tetap bisa dipertahankan. Paradigma multikultural yang marak didengungkan sebagai langkah alternatif dalam rangka mengelola masyarakat multikultur sebagaimana Indonesia tampaknya masih memerlukan perjalanan panjang dan berliku (Muqtafa, 2008). Gagasan genuine ini belum mampu diejawantahkan, baik oleh masyarakat maupun pemerintah, dalam tindakan praksis (Dantes, 2008). Phenomena legal-sosial sperti munculnya keinginan sekelompok orang supaya hukum-hukum yang bersumber dari agama yang dipeluknya dilegalisasi masuk ke dalam KUHP tanpa proses objektifikasi, merupakan potret riil belum dipahami dan dihayatinya potensi multikultur oleh sebagian besar masyarakat Indonesia.

Kasus RUU Kerukunan Beragama yang sangat kental dengan aroma intervensi negara yang deterministik dalam kehidupan umat beragama juga menandai betapa lemahnya nalar multikultural dalam benak bangsa Indonesia. Fakta ini merupakan sesuatu yang mesti menjadi keprihatinan semua komponen masyarakat, manakala menilik kembali latar sosiologis-antropologis bangsa ini. Indonesia adalah masyarakat majemuk, baik secara horizontal maupun vertikal. Secara horizontal berbagai kelompok masyarakat yang kini dikategorikan sebagai "Bangsa Indonesia" dapat dipilah-pilah ke dalam berbagai suku bangsa, kelompok penutur bahasa tertentu, maupun ke dalam golongan penganut

Jurnal Pendidikan Indonesia | 29 
ajaran agama yang berbeda satu dengan lainnya. Sementara secara vertikal berbagai kelompok masyarakat itu dapat dibedabedakan atas dasar mode of production yang bermuara pada perbedaan daya adaptasinya (Lasmawan, 2008). Pada konteks realitas-empirik, kenyataan ini justru kerap terabaikan, bahkan sengaja dilanggar untuk kepentingan-kepentingan kelompok tertentu. Fakta riil di lapangan, seringkali bukannya penghargaan dan pengakuan atas kehadiran yang lain akan tetapi upaya untuk "mempersamakan" (conformity) atas nama persatuan dan kesatuan.

Politik sentralisme kekuasaan yang pada masa Orde Baru memaksakan "monokulturalisme" yang nyaris seragam adalah bukti nyata belum dipahaminya multikultural oleh masyarakat, termasuk oleh para pengambil kebijakan hingga saat ini (Dantes, 2009). Selanjutnya dikatakan juga bahwa monokulturalisme ini telah memunculkan reaksi balik, yang mengandung implikasi-implikasi negatif bagi rekonstruksi kebudayaan Indonesia yang multikultural. Berbarengan dengan proses otonomisasi dan desentralisasi kekuasaan pemerintahan, terjadi peningkatan gejala "provinsialisme" yang hampir tumpang tindih dengan "etnisitas" yang mengarah pada "tirani minoritas dan dominasi mayoritas". Politik identitas kelompok, seiring dengan menggejalanya komunalisme, makin menguat, yang pada akhirnya memicu munculnya konflik antar suku maupun agama bak cendawan di musim hujan. Kesatuan dan persatuan yang diidamidamkan selama ini ternyata semu belaka, sehingga yang mengemuka kemudian adalah kepentingan antar suku, daerah, ras ataupun agama dengan mengesampingkan realitas atau kepentingan yang lain (Muqtafa, 2008 Dantes, 2008). Faktor lain yang turut menyebabkan mandulnya pendidikan multikultural pada tingkat praksis disinyalir disebabkan oleh masih dominannya wacana "toleransi" dalam menyikapi realitas multikultural tersebut.

Berdasarkan latar belakang masalah di atas, maka dapat diformulasikan rumusan masalah penelitian pada tahun 3 ini sebagai berikut: (1) bagaimanakah candraan materi dan kompetensi mata pelajaran IPS di kelaskelas awal sekolah dasar secara umum sesuai dengan kurikulum IPS 2006 yang saat ini dikembangkan oleh guru?, (2) bagaimanakah mekanisme pengembangan model pembelajaran multikultur dan buku ajar IPS berbasis multikultur yang berorientasi spiritualisme yang relevan bagi anak sekolah dasar pada kelas-kelas awal ? (3) bagaimanakah bentuk akhir dari model pendidikan multikultur dalam pembelajaran IPS menganut paradigma sekuensikarakteristik materi, sesuai dengan kurikulum IPS SD tahun 2006 ? (4) bagaimanakah bentuk dari instrumen penilaian pendidikan multikultur yang visibel untuk dikembangkan untuk anak sekolah dasar sesuai dengan kurikulum IPS SD 2006 ? dan (5) bagaimanakah bentuk akhir dari model pembelajaran berbasis multikultur dalam pembelajaran IPS untuk siswa kelas-kelas awal yang relevan dengan karakteristik kurikulum IPS SD 2006 ?. IPS merupakan salah satu mata pelajaran wajib yang harus dibelajarkan kepada siswa SD. Melalui pembelajara IPS akan dapat dibangun sumber daya manusia (SDM) Indonesia yang tangguh dan berkualitas serta memiliki wawasan dan keterampilan hidup bernegara sesuai dengan tata aturan perundang-undangan yang berlaku (Kurikulum IPS SD 2006). Esensi dari pembelajaran IPS adalah bagaimana menjadikan siswa sebagai warga negara

Jurnal Pendidikan Indonesia | 30 
yang paham dan sadar (literasi) akan hak dan kewajibannya sebagai warga masyarakat, bangsa, dan negara yang terikat oleh berbagai piranti hukum formal dan adat istiadat. Melalui IPS siswa dapat belajar dan melatihkan potensi dirinya secara optimal tentang tata cara hidup, menghadapi masalah, dan menyelesaikan masalah berdasarkan peraturan formal yang berlaku, sehingga terwujudnya stabilitas nasional yang kondusif (Lasmawan, 2005). Upaya pembangunan stabilitas nasional yang kondusif harus dilandasi oleh pemahaman yang memadai terhadap keberagaman suku bangsa dan adat istiadat yang dimiliki oleh bangsa Indonesia.

Pembelajaran IPS merupakan media strategis dalam pembentukan siswa menjadi warga masyarakat yang sociotable (Hasan, 2005). Pada pembelajaran IPS, siswa dibekali seperangkat kemampuan, pengetahuan, sikap, nilai, dan keterampilan sosial untuk hidup bermasyarakat (Kurikulum 2006). Schement (2002) dan Hasan (2005) menyatakan bahwa substansi dari pembelajaran IPS pada jenjang pendidikan dasar adalah bagaimana siswa mengenal diri dan lingkungannya, sehingga pada saat mereka telah terjun dalam realitas sosial kemasyarakatan dapat mewujudkan civic community.

Civic community menjadi target akhir dari pembelajaran IPS, namun pencapaian kearah itu memerlukan berbagai upaya dari guru, siswa, dan lingkungan sekitar secara holistik dalam format desain instruksional yang berbasis nilai-nilai lokal yang beragam. Integrasi pendidikan multikultur dalam pembelajaran IPS pada dasarnya sudah terlihat dari candraan kompetensi mata pelajaran tersebut (Kurikulum 2006).

Fakta di lapangan ternyata menunjukkan bahwa: guru belum mampu mengembangkan dan membelajarkan kompetesi pendidikan multikultur (Lasmawan, 2005). Mereka masih menekankan pada konsep dasar keilmuan dari materi tersebut, dengan mengabaikan "theother targets" dari candraan kompetensi yang ada pada struktur kurikulum, yaitu pendidikan multikultur. Hal ini terjadi, karena guru belum memiliki kemampuan dan keterampilan mengembangkan, mengorganisir, dan membelajarkan serta menilai kompetensi pendidikan multikultur (Lasmawan, 2005; Hasan, 2005). Penelitian yang dilakukan oleh Lasmawan (2005) tentang pengembangan model pendidikan nilai dalam pembelajaran IPS menunjukkan bahwa: hampir $65 \%$ guru tidak memiliki kurikulum mata pelajaran yang dibinanya, dan pembelajaran yang dilakukan sangat gersang dengan pesan nilai moral realistik yang sangat dibutuhkan oleh siswa dalam kehidupannya sehari-hari.

\section{METODE PENELITIAN}

Penelitian ini pada dasarnya bertujuan untuk merancang, mengembangkan, dan mengevaluasi perangkat pembelajaran, dan menganalisis kondisi-kondisi yang memfasilitasi penggunaan perangkat pembelajaran. Berdasarkan rasional tersebut, maka penelitian ini menggunakan desain penelitian pengembangan tipe "Prototipycal Studies" sebagaimana yang dikedepankan oleh Akker (1999) dan Plomp (2001). Hal penting yang perlu diperhatikan dalam penelitian pengembangan adalah kualitas perangkat pembelajaran (produk) yang dihasilkan. Plomp (2001), memberikan criteria kualitas produk yaitu valid (merefleksikan pengetahuan state-of-the-art dan konsisten internal), mempunyai nilai tambah (added value), praktis, dan efektif. Secara umum, Plomp (1999), menyatakan 
bahwa pelaksanaan penelitian pengembangan meliputi tiga fase yaitu: fase analisis hulu-hilir (front-end analysis), fase pengembangan prototipe (prototyping phase), dan fase penilaian (assessment phase) atau evaluatif sumatif. Karena penelitian ini ingin mengungkap secara mendalam tentang keterampilan proses, keterampilan berpikir, dan keterampilan berkomunikasi siswa maka, dalam fase pengembangan menggunakan metode studi kasus. Untuk mendapatkan jawaban secara empiris terhadap pertanyaan penelitian yang telah diajukan, data dalam penelitian ini akan dikumpulkan dengan studi pustaka, lembar validasi, lembar observasi, angket, tes hasil belajar, dan format wawancara. Secara rinci, teknik analisis data dalam penelitian ini dapat dijabarkan sebagai berikut: Data tentang phenomena didaktik, karakteristik siswa, karakteristik guru, dan kendala-kendala yang dialami oleh guru akan dianalisis secara expert judgment melalui panel group discussion, sementara untuk mengetahui validitas perangkat pembelajaran, data dianalisis secara deskriptif yaitu dengan tehnik distribusi frekuensi. Untuk mengetahui efektivitas perangkat pembelajaran pada uji coba II data dianalisis secara deskriptif, sedangkan data tentang tingkat multikulturalisme dan hasil belajar siswa pada fase penilaian dianalisis dengan statistic inferensial model multivariate analisis varian dua jalur.

\section{HASIL DAN PEMBAHASAN}

Hasil Penelitian

Candraan materi dan kompetensi mata pelajaran IPS di kelas-kelas awal sekolah dasar secara umum berisikan kompetensi yang terkait dengan: lingkungan, kesenangan diri (hobi), kebersihan, kerjasama, dan tempat-tempat umum (public area), yang tersaji secara berurutan sesuai dengan semester dan kelasnya. Sementara model pembelajaran yang saat ini banyak dikembangkan oleh guru adalah model ceramah dan penugasan rumah (PR), yang bagi siswa sangat membosankan dan kurang menarik minat belajar mereka. Siswa menempatkan pelajaran IPS sebagai mata pelajaran yang membosankan dan kurang menarik untuk dipelajari, karena materinya terlalu sulit dan bersifat hapalan, dan guru dalam menyampaikan materinya seperti "penjual obat" di pasar-pasar, yaitu hanya ceramah dan menyampaikan cerita itu-itu saja.

Pengembangan model pembelajaran multikultur dan buku ajar IPS berbasis multikultur yang berorientasi spiritualisme dilakukan dengan mekanisme sebagai berikut: (1) fokus group discussion, (2) individual perspektif, (3) seminar dan lokakarya, (4) simulasi model, dan (5) justifikasi dan validasi model. Adapun struktur materi pendidikan multikultur yang dikembangkan dalam pembelajaran IPS dan PKn disesuaikan dengan karakteristik dari masing-masing mata pelajaran dan candraan Standar isi (SI), standar kompetensi (SK), dan kompetensi dasar (KD) dari masing-masing mata pelajaran pada setiap semesternya. $\mathrm{Di}$ sisi lain, sebelum menerapkan model pembelajaran dan aplikasi materi multikultur, kepada guru direkomendasikan beberapa prinsip dasar, yaitu: kaji secara matang karakteristik materi ajar sebelum merancang dan memasukkan materi pendidikan multikultur kedalam satuan mata pelajaran IPS dan/atau PKn, (2) identifikasi kemultikulturan siswa dan lingkungan masyarakatnya, (3) refleksi kemampuan dan keterampilan diri, serta akses informasi kemultikultural yang tersedia, dan (4) penyajian pembelajaran 
yang berpusat kepada siswa, sehingga dominasi pembelajaran tidak lagi ada di tangan guru. Buku petunjuk guru yang akan dikembangkan dalam penelitian tahun ke-2 akan ditata sedemikian rupa, dimana bagian kiri merupakan bagian yang ada pada buku siswa (sama dengan apa yang terdapat pada buku siswa), sedangkan di sebelah kanannya berupa petunjuk dan komentar apa yang semestinya dilakukan oleh guru dan siswa. Hal ini hanya sebagai stimulan saja, dimana guru bebas mengembangkan atau memodifikasi sesuai dengan kebutuhan dan situasi pembelajaran yang dihadapinya.

Bentuk akhir dari model pendidikan multikultur dalam pembelajaran IPS menganut paradigma sekuensi-karakteristik materi, yaitu sebaran materi multikultur disesuaikan dengan karakteristik materi yang muncul di setiap semester dan kelas pada masing-masing mata pelajaran, sehingga tidak mengabaikan struktur kurikulum yang telah ditetapkan. Sementara pokok-pokok materi pendidikan multikultur yang visibel dikembangkan dalam pembelajaran IPS secara integralistik dan holistik adalah: Ideologi Pancasila/UUD 1945, Bahasa Indonesia, Bendera Kebangsaan, Lagu Kebangsaan, Bhineka Tunggal Ika, Peraturan Perundangundangan, Tat Twam Asi (Persaudaraan Universal), Ahimsa (Anti Kekerasan), Karma Phala (Hukum Karma), Tri Hita Karana (Ekosentrisme/ Kosmosentrisme), Rwa Bhineda (Dualisme Kultural/Oposisi Biner), Desa, Kala, Patra (Pluralisme), Menyama Braya (Solidaritas Sosial/Modal Sosial), Tri Samaya (Kesadaran Sejarah), Skriptualisme, Intuisionisme, Rasionalisme, Empirisme, Keragaman, Kebersamaan, Kesetaraan, Kesejahteraan, Kemanusiaan, Proporsional, Keadilan, Anti hegemoni dan Demokratis, Dominasi, Toleransi,
Keterbukaan, Dialogis, Adaptif, Kejujuran, Empati, Tanggung jawab, Altruisme, dan Kerjasama. Sementara model penilaian yang dikembangkan untuk pendidikan multikultur adalah penilaian proses, penilaian hasil, dan penilaian kinerja. Bentuk dari instrumen penilaian pendidikan multikultur yang visibel untuk dikembangkan antara lain: (1) self-esteem, (2) penilaian kinerja, (3) skala sikap, (4) tes keterampilan sosial, (5) penilaian literasi sosial-budaya, (6) skala sikap, (7) tes keterampilan berpikir, (8) penilaian proyek, dan (9) penilaian patnershif (penilaian antar siswa). Bentuk akhir dari model pembelajaran berbasis multikultur terdiri dari komponen-komponen yang sinergis mutualis dengan tahapan: (1) inisiasi, (2) eksplorasi, (3) eksplanasi, (4) peer group analisis, (5) expert-opinion, dan (6) refleksi-perumusan komitmen.

Setelah dilakukan uji terbatas terhadap model multikultur dalam pembelajaran IPS, ternyata siswa yang dibelajarkan dengan model pembelajaran berpendekatan multikultur memiliki prstasi belajar yang lebih baik dibandingkan dengan siswa yang dibelajarkan dengan model konvensional, baik pada siswa yang memiliki sikap spiritualisme tinggi, maupun siswa yang memiliki sikap spiritualisme rendah.

Perbedaan antara hasil belajar antara kedua kelompok di atas disebabkan karena pada kelompok siswa yang mengikuti pembelajaran dengan pendekatan belajar multikultur dan memiliki sikap spiritualisme tinggi terjadi proses meaningfull learning, yaitu melalui pemahaman konsep secara utuh. Pemahaman konsep secara utuh ini dilakukan dnegan jalan mengakomodasi konsep dari yang telah dimilikinya dengan sesuatu yang baru yang dibelajarkan oleh guru. Sedangkan pada siswa yang mengikuti pembelajarn dengan pendekatan 
konvensional terjadi proses belajar dengan pola transfering secara utuh, sehingga pemaham konsep secara utuh akan lebih lambat terjadi. Siswa kelompok ini hanya menghapalkan konsep generalisasi IPS yang bersifat hafalan saja; sehingga bila terjadi keragu-raguan terhadap konsep dan generalisasi tersebut siswa tidak akan mampu mengakomodasikan konsep dan generalisasi itu secara tepat dan utuh pada dirinya.

\section{Pembahasan}

Berorientasi pada temuan penelitian di atas, maka pengembangan model pendidikan multikultur berbasis spiritualisme dalam pembelajaran IPS Sekolah Dasar, baik yang berupa buku pegangan siswa, media pembelajaran, dan buku petunjuk guru akan dilakukan sesuai dengan kondisi riil saat ini di lapangan, sehingga ke depannya lebih mudah untuk melakukan revisi atau evaluasinya. Sikap spiritualisme siswa menurut takaran Dewey (Zambroni, 2001), pada dasarnya merupakan sebuah penegasan dari konsep dasar spiritualisme yang berkembanga pada abad pertengahan, dimana dia mengatakan bahwa; ide pokok spiritualisme adalah pandangan hidup yang dicerminkan dengan perlunya partisipasi dari setiap warga yang sudah dewasadalma membentuk nilai-nilai yang mengatur kehidupan bersama. Dewey menekankan bahwa spiritualisme merupakan keyakinan, suatu prinsip pertama dan paling utama yang harus dijabarkan dan dilaksankan secara sistimatis dalam bentuk aturan sosial politik. Sesungguhnya menurut Dewey spiritualisme bukan sekedar menyangkut bentuk pemerintahan melainkan yang utama adalah suatu bentuk kehisupan bersama dalam bermasyarakjat dan berbangsa. Pada tataran konsep yang berbeda, Ubaidillah
(2004), menyatakan bahwa; menata spiritualisme melalui pendidikan masih belum terinstitusionalisasi secara sistimatis di Indonesia. Padahal, di negara-negara maju, terutama Amerikan Serikat dan Eropa, pendidikan spiritualisme adalah bagian tak terpisahkan dari sistim pendidian mereka. Sebagai output dari pendidikan yang demokratis, kedewasaan warga negara dalam berspiritualisme di barat bisa menjadi referensi adanya keterkaitan antara sikap demokratis warga negara dan program pendidikan spiritualisme, populer dengan sebutan civic education (IPS) yang ditempuh melalui jalur pendidikan formal.

Bagi negara yang tengah bertarnsisi menuju spiriyualisme seperti Indonesia, IPS yang mamp memperkuat barisan masyarakat civil yang beradab dan demokratis amat pending dilakukan. IPS bukanlah barang baru dalam sejarah pendidikan nasional. Di era Soekarn, misalnya, IPS dikenal sebagai pendidikan Civic. Demikian pula masa Presiden Soeharto, IPS sangat intensif dilakukan dengan bermacam nama singkatan. Sayangnya, pelaksanaan IPS semasa Orde Baru, seperti Pendidikan Moral Pancasila (PMP) dan Penataran Pedomana Pengayatan dan Pengamalan Pancasila (P4) ternyata menyimpang dari impian luhur kemanusiaan yan terkandung dalam dasar negara Pancasila. Bentuk masyarakat demokratis akan tumbuh kokoh jika di kalangan masyrakat tumbuh kultur dan nilainilai spiritualisme. Nilai-nilai spiritualisme yang diterapkan di masyarakat menurut Zambroni (2001:33), adalah toleransi, bebas mengemukakan dan menghormati perbedaan pendapat, memahami keanekaragaman dalam masyrakat, terbuka dalam komunikasi menjunjung nilai dan martabat manusia, tidak menggantungkan

Jurnal Pendidikan Indonesia | 34 
diri pada orang lain, saling menghargai, mampu mengekang diri, kebersamaan dan keseimbangan. Lebih lanjut ( Sihabuddin, 2002: 144), menjelaskan nilai-nilai demokratis itu adalah mengakui persamaan derajat, menghargai pihak lain, mau bekerja sama, menghargai pendapat orang lain, menerima dan menghargai perbedaan kultur dalam masyarakat, peka terhadap kesulitan orang lain, berlaku adil, memiiki kemampuan berpartisipasi dalam kehidupan politik dan sosial. Nila-nilai spiritualisme tersebut hendaknya dapat diaktualisasikan di dalam kehidupan nyata melalui suatu tranformasi. Dengan demikian, daat disimpulakn bahwa sikap demokratis adalah predisposisi seseorang terhadap salah satu aspek sosial yakni spiritualisme. Pengetahuan tentang spiritualisme akan mendorong orang untuk bertindak sesuai dengan nila-nilai spiritualisme.

Ada beberapa faktor yang mempengaruhi sikap demoratis siswa. Menurut Purnomo(1999: ii) beradasarkan hasil menelitiannya bahwa sikap demokratis siswa dipengaruhi oleh banyak faktor yang saling kait-menkait, seperti guru, teman, orang tua, dan media massa. Keseluruhan unsur ini saling berinteraksi dalam pikiran siswa, yang menghasilakn sikap demokratis. Tujuan dari demokratisasi pendidikan adalah menghasilkan lulusan yang merdeka, berpikir kritis dan sangat toleran dengan pandangan dan praktik-praktik spiritualisme (Suryadi, 1999: 23).

Secara konseptual, IPS adalah suatu bentuk pendidikan yang memuat unsurunsur pendidikan spiritualisme yang berlaku universal, dimana prinsip umum spiritualisme yang mengandung pengertian mekanisme sosial politik yang dilakukan melalui prinsip dari, oleh, dan untuk warga negara menjadi fondasi dan tujuannya.
Mengacu pada realitas spiritualisme di Indonesia, pendidikan spiritualisme yang di subordinasikan dalam IPS dengan konsep itu sudah saatnya dilakukan. Tujuan pendidikan ini adalah untuk membangun kesadaran peserta didik akan hak dan kewajibannya sebagai warga negara dan mampu menggunakannya secara demokratis.

Substansi dari pembelajaran IPS adalah bagaimana melalui interaksi transaksional yang kreatif, siswa dibekali seperangkat kemampuan, pegetahuan, sikap, nilai, dan keterampilan sosial untuk hidup bermasyarakat. Sejalan dengan konsep ini, Schement (2002) menyatakan bahwa substansi dari pembelajaran IPS pada jenjang pendidikan dasar adalah bagaimana siswa mengenal diri dan lingkungannya, sehingga pada saat mereka telah terjun dalam realitas sosial kemasyarakatan dapat mewujudkan civic community.

Civic Community menjadi target akhir dari pembelajaran IPS, namun pencapaian ke arah itu memerlukan berbagai upaya dari guru, siswa, dan lingkungan sekitar secara holistik dalam format design instructional yang berbasis nila-nilai lokal yang beragam. Salah satu komponen dasar dari pembelajaran IPS menuju terwujudnya civic community adalah pendidikan multikultur ( NCSS, 2004). Dilihat dari perspektif kepentingan belajar siswa, pembelajaran dengan pendekatan multikultur telah memberikan keleluasaan yang optimal bagi siswa untuk mengembangkan dan melatih kemampuan serta ketrampilan belajaranya, sehingga berpengaruh langsung terhadap prestasi belajaranya. Hal ini sejalan dengan apa yang diketengahkan oleh NCSS (2004) bahwa pembelajaran dengan pendekatan multikultur akan memberikan kesempatan

Jurnal Pendidikan Indonesia | 35 
yang optimal kepada siswa untuk mempelajari materi menurut perspektif dirinya dan ditunjang dari apa yang dibejaran oleh guru. Artinya, siswa bukan semata-mata memperoleh sesuatu atau informasi dari guru, melainkan mereka secara aktif mencari dan membuat kesimpulan sendiri menurut perspektif dan nila yang dianutnya.

Melalui pendekatan multikultur, pembelajaran yang dikembangkan oleh guru lebih menempatkan siswa dalam iklim pembelajaran yang memungkinkan mereka memadukan berbagai spektrum pengalaman belajar sehari-hari (di luar kelas) dengan berbagai spketrum pengalaman belajar di dalam kelas dalam latar yang alamiah. Artinya pembelajaran yang dikembangkan oleh guru telah mampu menjembatani kesenjangan yang selama ini terjadi dalam pembelajaran IPS, yaitu keputusannya apa yang dipelajari di sekolah dengan realitas kehidupan yang dijalani siswa sehari-hari. Realitas ini sejalan dengan perspektif teori konstruktifisme sosialnya Vygotsky (Lasmawan, 2004), yang merupakan salah satu pilar pengembangan pendekatan multikultur yang mengedepankan bahwa siswa memperoleh banyak pengetahuan di luar kegiatan pembelajaran sekolah, sehingga pembelajaran yang dilakukan oleh guru semestinya memperhatikan hal tersebut dan menunjang perkembangan proses alami (latar sosial) di dalam kelas.

Melalui pengembangan iklim pembelajaran sebagaimana dideskripsikan di atas siswa akan merasa dekat dengan materi yang dibelajarkan oleh guru. Makna dari realitas ini adalah bahwa pengembangan pendekatan multikultur dalam pembelajran IPS, membawa implikasi pada perluasan sumber belajar sampai menembus dinding-dinding kelas. Perluasan sumber belajar ini, secara singnifikan berpengaruh terhadap tingkat dan keluasan pemahaman materi oleh siswa. Hal ini terjadi, karena perluasan sumber belajar ini akan menyebabkan semakin komprehensifnya informasi yang dapat diakses oleh siswa.

Guru yang dilibatkan dalam penelitian ini sebagai guru mitra rata-rata berkualifikasi Strata 1 (S1), sehingga telah memenuhi persyaratan minimal sebagaimana yang diharuskan oleh PP Nomor 19 Tahun 2005 tentang Standar Nasional Pendidikan, khususnya yang mengatur tentang standar pendidikan tenaga pendidik (guru) sekolah dasar. Sementara dilihat dari karakteristik kelaminnya, sebagian besar adalah guru perempuan. Di sisi lain, dilihat dari pengalaman mereka mengikuti pelatihan atau pertemuan ilmiah yang terkait dengan pengembangan profesinya, rata-rata telah mengikutinya lebih dari 10 kali. Hal ini tentu sangat membantu dalam kaitannya dengan pelaksanaan tugas dan kewajibannya sebagai tenaga profesional dalam bidang ke-IPS-an. Pengalaman ini sebenarnya sangat membantu guru dalam merancang dan melaksanakan pembelajaran yang inovatif. Akan tetapi dilihat dari pengelolaan pembelaran di kelas, guru cenderung menerapkan pembelajaran individual. Sumber pembelajaran yang digunakan adalah buku siswa. Guru mengajar mengikuti materi yang ada pada buku siswa, serta langsung merespon siswa tanpa memberi kesempatan siswa lainnya untuk memberi komentar.

Phenomena didaktik yang dapat digunakan sebagai sumber pembelajaran untuk siswa Kelas I adalah permainan, lingkungan , kebun, diri sendiri, dan keluarga, sedangkan untuk kelas II adalah

Jurnal Pendidikan Indonesia | 36 
disampaikan oleh guru dari ketiga lokasi sekolah, relatif sama yaitu permainan, ke pasar, pengukuran benda, makanan, lingkungan, kegiatan sehari-hari, permainan, kegemaran, dan badan. Semua fenomena didaktik ini sesuai dengan semua anak untuk semua lokasi. Oleh karena itu, sebagai fenomena didaktik yang digunakan sebagai tema adalah lingkungan keluarka, kebun, pasar, sekolah, serta kegiatan sehari-hari. Dilihat dari usia guru yang mengajar di kelas I dan II dominan mempunyai umur lebih dari 40 tahun, serta berjenis klamin perempuan. Kiranya pertimbangan guru senior dan sosok perempuan dijadikan sebagai pertimbangan untuk guru kelas I dan II. Hal ini dapat dipahami karena siswa kelas I dan II yang umurnya sangat muda memerlukan sosok guru yang sabar dan dapat "melindungi", serta "mendidik". Kondisi ini tentu sangat menguntungkan bagi pelaksanaan penelitian ini, khususnya pada saat pengembangan model yang merupakan fokus dari penelitian pada tahun ke-2 (tahap II). Kedewasaan umur dan kematangan akademik guru ini, sangat berkontribusi pada saat dilakukannya perancangan model perangkat pembelajaran yang akan dilakukan pada tahun kedua.

Bertalian dengan hambatan atau kendala yang dihadapi oleh guru dalam membelajarkan materi IPS saat ini, kebanyakan guru menyatakan bahwa mereka kesulitan dalam menyampaikan materi dalam bentuk cerita atau menggunakan pendekatan tematik. Hal ini disebabkan karena mereka belum memiliki pemahaman dan keterampilan dalam pembelajaran pendidikan multikultur. Pada sisi lain, keterbatasan media pembelajaran dan sumber belajar merupakan kesulitan lain yang sangat dirasakan oleh guru dalam membelajarkan IPS saat ini. Bertalian dengan hal itu, pengembangan model pendidikan multikultur berbantuan modul berbasis masalah yang berorientasi pada spiritualisme dalam pembelajaran IPS-SD yang menjadi fokus dalam penelitian ini sangat dibutuhkan untuk mengatasi kondisi ini.

\section{KESIMPULAN}

Berdasarkan hasil penelitian dan pembahasan di atas, dapat diformulasikan kesimpulan sebagai berikut: (1) candraan materi dan kompetensi mata pelajaran IPS di kelas-kelas awal sekolah dasar secara umum berisikan kompetensi yang terkait dengan: lingkungan, kesenangan diri (hobi), kebersihan, kerjasama, dan tempat-tempat umum (public area), yang tersaji secara berurutan sesuai dengan semester dan kelasnya. (2) Pengembangan model pembelajaran multikultur dan buku ajar IPS berbasis multikultur yang berorientasi spiritualisme dilakukan dengan mekanisme sebagai berikut: fokus group discussion, individual perspektif, seminar dan lokakarya, simulasi model, dan justifikasi dan validasi model. (3) Bentuk akhir dari model pendidikan multikultur dalam pembelajaran IPS menganut paradigma sekuensikarakteristik materi, yaitu sebaran materi multikultur disesuaikan dengan karakteristik materi yang muncul di setiap semester dan kelas pada masing-masing mata pelajaran, sehingga tidak mengabaikan struktur kurikulum yang telah ditetapkan. (4) Bentuk dari instrumen penilaian pendidikan multikultur yang visibel untuk dikembangkan antara lain: self-esteem, penilaian kinerja, skala sikap, tes keterampilan sosial, penilaian literasi sosial-budaya, skala sikap, tes keterampilan berpikir, dan yang lainnya. (5) Bentuk akhir dari model pembelajaran Jurnal Pendidikan Indonesia | 37 
berbasis multikultur terdiri dari komponenkomponen yang sinergis mutualis dengan tahapan: (a) inisiasi, (b) eksplorasi, (c) eksplanasi, (d) peer group analisis, (e) expert-opinion, dan (f) refleksi-perumusan komitmen. Dan (6) setelah dilakukan uji terbatas terhadap model multikultur dalam pembelajaran IPS, ternyata siswa yang dibelajarkan dengan model pembelajaran berpendekatan multikultur memiliki prstasi belajar yang lebih baik dibandingkan dengan siswa yang dibelajarkan dengan model konvensional, baik pada siswa yang memiliki sikap spiritualisme tinggi, maupun siswa yang memiliki sikap spiritualisme rendah.

Berdasarkan kesimpulan di atas, maka dapat diformulasikan saran sebagai berikut: Perlu diperhatikan secara khusus aspek budaya lokal yang menghambat proses pembelajaran, sehingga para guru tidak terkontaminasi oleh hal-hal lain di luar dimensi akademiknya. Di sisi lain, dalam perancangan dan pelaksanaan pembelajaran guru disarakan menggunakan masalah aktual dan faktual atau tema yang dekat dengan kehidupan anak. Selama pelaksanaan pembelajaran, guru perlu dilatihkan kesabaran lebih dalam menunggu apa yang dipikirkan oleh anak, kemudian memberi kesempatan untuk mengemukakan dan merespon bagi siswa yang lain, sehingga aktivitas belajar tidak berlangsung satu arah, yaitu dari guru ke siswa sematamata.

\section{DAFTAR PUSTAKA}

Aikenhead, G. (1999). "The Integration of Skills Process into Science Education". Social Science Bulletin, 31 (1), 27-35.

Beyer, B. K. (1979). Teaching Thinking in Social Studies: Using Inquiry in the Classroom. Columbus: Charles E.
Meril Publishing Company \& A Bell \& Howell Company.

Cartwright, J. (1999). Cultural Transformation: Nine Factors for Continuous Business Improvement. Great Britain: Prentice Hall.

Chapin, J. R. and Messik, R. G. (1989). Elementay Social Studies: A Practical Guide. New York \& London: Longman Group Ltd.

Cleaf, D. W. V. (1991). Action in Elementary Social Studies. USA: Allyn \& Bacon.

Djahiri, K. (2003). Profil Guru IPS Masa Depan. (Makalah). Disajikan pada Seminar Nasional Pendidikan di Jakarta tahun 1994.

Hasan, S. H. (2006). "Tujuan Kurikulum Pengetahuan Sosial". Jurnal Pendidikan IImu Sosial (JPIPS). (1). Halaman 100

Kertih, W. (2005). Pengembangan model klarifikasi nilai untuk meningkatkan keterampilan analisis nilai siswa sekolah dasar (laporan penelitian). Singaraja: IKIP Negeri Singaraja

Lasmawan, W. (2006). Pengembangan Modul Berwawasan Konstruktivis dalam Pembelajaran IImu Politik dan Sistim Politik Indonesia pada Mahasiswa Program Studi PPKN IKIP Singaraja. (laporan penelitian). Singaraja: IKIP Negeri Singaraja

Pederson, J.E. (1996). The Jurisprudential Model of Study for Skill Proccess in Social Studies. ICASE Yearbook.

Shaver, J. P.(Ed). (1991). Handbook of Research on Social Studies Teaching and Learning: $A$ Project of the National Council for the Social Studies. New York, Toronto: MacMillan Publishing Company.

Stopsky, F \& Sharon L. (1994). Social Studies in a Global Society. America, Canada: Delmar Publishing Inc.

Wahab, A. (2005). Inovasi Pembelajaran IImu Sosial yang Berorientasi Kompetensi. (makalah). Seminar Nasional HISPISI di IKIP Negeri Singaraja. Tanggal $17 \quad-\quad 19$

Jurnal Pendidikan Indonesia | 38 
September 2005. HISPISI Cabang Bali.

Waterworth, Peter. (2002). The Spirit of Cooperation: Using cooperative learning strategies in teacher education in Australia and Thailand. Thailand: UNESCO-ACEID. 